ORCID 0000-0002-5355-8565

Daria E. Kardashenko Lecture

Stroganov Moscow State Academy of Design and Applied Arts e-mail: dkardashenko@gmail.com Moscow, Russia

ORCID 0000-0001-5707-5319

DOI: 10.36340/2071-6818-2021-17-4-110-123

\title{
ARTISTIC POTENTIAL OF DIGITAL GRAPHICS MODELLING. CONVERGENCE OF TRADITIONAL AND MULTIMEDIA EXHIBITION MEANS FOR DISPLAY OF DIGITAL ARTWORKS
}

Summary: The article considers the artistic potential of computer graphic modeling on the example of modern exhibition events that implement the convergence of traditional and multimedia exhibition facilities in the demonstration of digital art. Modern trends in multimedia transformation of exhibition spaces are outlined. The study resulted in recommendations for the optimal organ-

\section{Introduction}

The main goal of this study is to analyze the impact of modern digital graphic modeling capabilities on the process of art creation. The research area is an overview of the current state of digital graphic art, its artistic potential, the main available means of expression as well as an analysis of the prospects for displaying works of digital art in an environment that combines traditional and multimedia exhibition facilities.

1.1. The value of the digital graphical simu-

\section{lation in contemporary art.}

Born in the 60 s of the $X X$ century, compute graphics has gone a long way from early experiments for scientific and technical needs and individual special effects in large-budget films in the ization of the environment for displaying hybrid as well as digital works of art. The conclusions on the prospects for the development of innovative exhibition spaces will allow to optimize the functioning of the exhibition environment with a growing share of digital graphic content. Key words: digital arts, multimedia exhibition, VR/A applications in GLAM, gamification in arts expositions.

$70 \mathrm{~s}$ and $80 \mathrm{~s}$ to a strong position in various forms of art in the 90s. The modern era demonstrates the total dominance of digital technologies in the mass market of artistic content. This is due both to the huge variety of artistic expression tools provided by modern graphic modeling tools and to the high of the digital environment. This process is influenced by the factor of flexible integration of various types of content and the convenience of interaction between individual artists. Together, this gives a transition to a new level of artistic expression, while radically increasing the number of works created annually in the world. A significant reduction in the cost caused by the introduction of digital modeling allows moderate-sized teams to implement animation and cinematic projects that were previously created by large teams, at great expense and for a long time. Similarly, small teams and even single designers equipped with a rich arsenal of software and hardware can cope with the volume of architectural and environmental creativity unavailable in the classical era.

1.2. The current trend of convergence of traditional and multimedia display.

The explosive growth in the penetration of digital graphic technologies in the process of creating artistic works dictates the need to create new kind of exhibition spaces. In many cases digital technologies do not replace traditional art works and do not create specialized digital exhibition spaces but rather converge traditional and digital art in a single exhibition environment. This allows one to significantly expand the target audience, diversify the impressions received by visitors and get a positive response from visitors to the exhibition that contributes to the commercial success of exhibitions and increase the public importance of graphic art.

2 Areas of application of digital tools for graphic arts.

\section{.}

The first computer games began to appear as experiments of computer enthusiasts soon after the first computers appeared. Graphic capabilities and availability of computers grew rapidly: in the 70-80 years widely available gaming systems with two-dimensional graphics began to appear that were followed in 90 's by three-dimensional game graphics. At the turn of the century the use of hardware acceleration capabilities for three-dimensional graphics became mainstream. most gaming systems received a specialized computer-a graphics processor with hardware acceleration capabilities for rendering polygonal graphics in real time. In the first decade of the twenty-first century video cards first gained the ability to speed up shading and by the end of the decade turned to high-performance multithreaded computers for general-purpose tasks. In relation to the tasks of digital art such an increase in available computing power has led to the following main trends:

- The graphic design of three-dimensional computer games is rapidly becoming more complex, the applied models are moving in the direction of cinematic complexity and the quality of the resulting image gradually tends to photorealistic.

- Software systems for implementing the game environment become a powerful tool for creating three-dimensional interactive art objects. Just as in the case of graphics processors: mass production contributes to the low cost of hardware and the mass market for game software contributes to th availability of complex game development tools for use even in single art objects.

- The introduction of artificial intelligence elements in interactive exhibition objects allows on to transform exhibition spaces, making the user's participation in the system as simple as possible allowing one to involve a visitor to a traditiona museum in a virtual environment without anyone's assistance. Modern means of data input into a com puter which are the development of modern gaming input devices allow one to capture the user's movement, face recognition and other body parts The real-time processing can be resulted either as static two-dimensional images or three-dimensional animation with the user's participation.

- An important role in the exhibition spaces of popular science such as technical and natura science museums is played by systems (similar to computer games) for interactive visual simulation of required natural phenomena and technical objects.

Modern museums are able to create with moderate costs simulators that give the visitor a new leve of experience compared to traditional static exhibits. This allows one to effectively engage the modern mass visitor that is used to the abundance of available audio-visual content. This is especially important for exhibition spaces aimed at children and youth audiences. On the other hand, the hardware and software unification of an interactive simulator with three - dimensional game systems provides unique opportunities for creating accessible remote interactive simulation systems. The current state of affairs in this area is radically different from the situation of 30-40 years ago. Then computer three-dimensional graphics and interactive simulators created on its basis required the use of ex pensive graphic stations and could be used either only in the place of their installation (usually in industry, being unavailable for wide exhibition us due to the high cost), or serve as tools for the production of replicated visual works without interactive use. Quite contrary, modern systems based on mass commercially available components are being actively implemented. For example Wargaming company together with representatives of the Ministry of defense of the Russian Federation place an interactive multi-touch panel in the Central Mu- 
seum of the armed forces of the Russian Federation in Moscow in 2016 where historically accurate $3 \mathrm{D}$ models of more than fifty warships of the main classes of the five superpowers of the world wars of the $\mathrm{XX}$ century are presented in detail. Visitors were given the opportunity to get acquainted with 3D models each of which could be viewed in detail from any angle and from any angle, turning them from side to side, zooming in and out on the touch screen. All models were accompanied by historical references and tactical and technical characteristics. [4] It should be noted that this exhibition too repeats a part of the functionality of a commercia Wargaming product - an online game "World of Warships", a simulator of naval battles, and creating such an interactive stand is very cost-effective in comparison with the autonomous development of an exhibition stand since both the ready-made game engine and the graphic content already available in the game are used.

- At the intersection of computer games and industrial computer graphics, virtual and augmented reality systems have emerged and developed rapidly. As with mass-market gaming systems themselves, the reduced cost of switching to mass production made virtual reality tools available to a wide audience and combined stationary Museum complexes of $V R$ and $A R$ art displays with remote technologies based on well-established and popular standards of mass-market gaming systems. Russian State Museum of Fine Arts named after A. S. Pushkin introduced the Artefact AR application, free to download on the App Store and Google Play. Pointing the camera of a mobile device to an exhibit marked with a sign one can view all the information directly on the screen of the device - to find out historical facts about it or, for example, compare how the work looked before restoration and in the process of restoration work. [4]

Fig. 1.

The Department of environmental design and multimedia design in Moscow State Stroganov Academy of Design and Applied Arts named after S. G. Stroganov in the framework of the training programs "Game design", "Motion design", "Design", "Development interfaces", "Animation" actively seeks to appeal to modern trends to create a virtual exhibition space available in the form of Internet sites, design augmented reality app enabling digital transformation of the existing natural, industrial or urban environment, exhibition and educational needs, and also to give wide multimedia functionality of traditional exhibition environments - exhibitions, museums, sightseeing programs, modernizing the existing art formations under modern conditions through media reconstruction.

The diagram in Fig. 2.

- The formation of the mass gaming industry and its strong cultural integration gave rise to such a new social phenomenon in the organization of various social processes as gamification. The essence of gamification is the application of game elements and mechanics outside of the actual game process. Gamification allows one to effectively motivate people based on natural needs for the element of excitement, getting a regular flow of evaluated achievements and similar sources of emotions that avoid obvious pressure and other negatively perceived mechanisms.

Gamification is being implemented with great success in various branches of human activity. In relation to the popularization and educational function of museums gamification allows one to replace surveys and other formal methods of testing the perception of the studied material with a game in which the tested visitor is interested in demonstrating the knowledge obtained. In the case of prolonged immersion by installing an application with gamification elements on a personal smartphone the consumer will be motivated to visit and study of a vide number of exhibition spaces.

2.2. Art installations using graphic digital modeling

Computer technologies often perform not only secondary technical functions for displaying works of traditional art or bringing interactivity to the exhibition environment but can also take place as self-valuable art objects. The number of artists who prefer to use only a virtual environment in their work is increasing with each new year. One example is the American artist Andrew "Android" Jones who calls his exclusively digital works "mirror purgatory" and calls the main goal of his work to change the perception of reality and the immersion of human consciousness in virtual reality.

If the creative research of Android Jones lies mainly in the plane of 2D graphics, the work of the President of the Creative Union of artists Konstantin Khudyakov who is called the "pioneer of Russian digital sculpture" is based on working with three-dimensional graphics. "He replaced marble and chise with 3D Studio Max, AutoCad, and 3D printer" [5]

Цифровое

искусство

Традиционные художественные материалы

Механика электрика, электронные компоненть

\section{ифровой контент \\ Мультимедиа \\ Инфраструктура}

связи и хранения

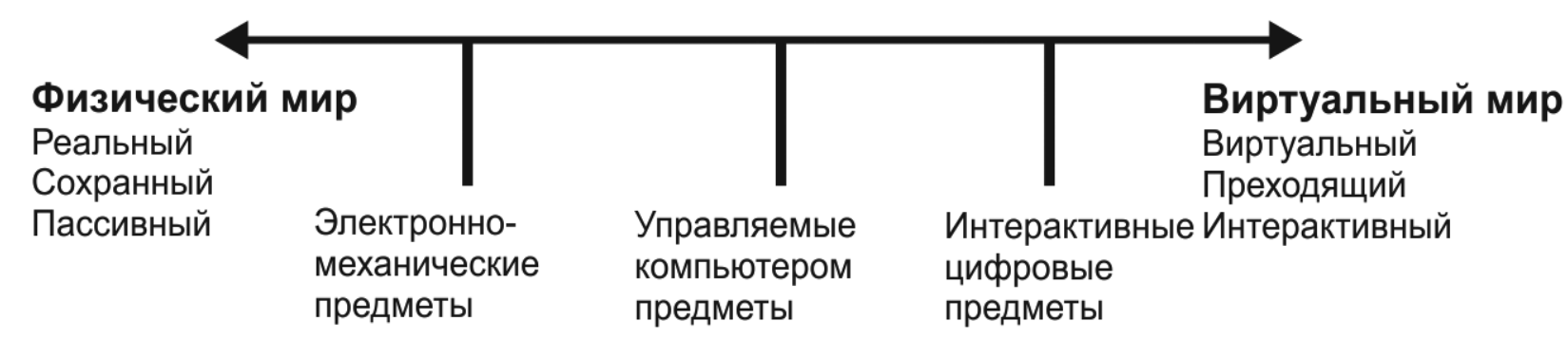
Fig. 1. Interrelation of tools and materials of artistic expression for various ratios of physical and
virtual level of realization of artistic objects in the context of convergent art. [1]

Законченный медиапродукт 
2.3 The Artistic potential of digital graphics as part of a continuous space of multimedia com puter arts.

The considered areas of application of digital media are corresponding to the general specifics of digital art which inextricably combines together digital media and computer technology that works with them, the concepts of traditional art that existed separately as a creative tool and raw artistic materials.

This type of connection allows the artist to move away from the straightforward transfer of traditional types and genres of fine art to the digital environment and engage in creative search in an integrated environment of digital art which combines a variety of modeling, visualization and parameterization tools including interactive.

Due to the deep mutual penetration of trans formed classical art forms in a multimedia digital environment, it is not surprising that certain types of art are blurred in the realities of the computer creative process. In modern conditions, the primary importance for the success of a digital art work is the management of its cycle of creation and exposure, taking into account the current realities of the socio-cultural environment. This factor is becoming a key one in terms of universal civilization the mechanisms of delivery and display of media content when the lack of availability and exclusivty of media copy (the traditional attributes of fine art) are no longer dominant factors in attracting interest to the product. The main point for the success of art events in such conditions is the creation of a sufficiently extensive and at the same time integral ideological and content environment which allows the visitor to get a fundamentally different aesthetic experience in relation to the clip-based everyday environment.

The diagram in Fig. 2 demonstrates the modern vision of the digital art creation cycle as a means of achieving global cultural goals - bringing the creative idea embodied in the means of artistic expression to the public, by using the optimization of the means of demonstration as an integral part of the cycle of creating an art object.

3. Convergence of traditional and multimedia

exhibition facilities in the display of digital art

3.1 The emergence and development of immersive art forms.

The effect of presence, the "immersion" of the viewer in the atmosphere created by the visual art- work was a desired goal long before the emergence of digital art. Large-scale pictorial panels, combining easel, monumental and decorative paintings in a single space, pictorial and graphic illusions, panoramas, means of projecting static images and cinema with increasing panoramas, up to full-dome projection - all these tools were used to enhance the impression of artistic works. However, only with the advent of multimedia tools of digital art, it became possible to achieve full-fledged immersiveness. Modern means of displaying works of digital art allow one to capture the viewer's attention most completely without extraordinary expenses for the production of graphic and accompanying content and for demonstration means, to convey the artistic intent by simultaneously affecting various senses and, if necessary, to supplement the impression with elements of interactivity.

The modern use of immersive exhibition spaces covers a wide range of variations [7], from the transformation of classical paintings into immersive exhibition spaces [8] and up to the creation of specialized multimedia works for an immersive en vironment. In addition to art exhibitions, immersive spaces are also successfully used in the scientific and educational exhibition environment.

3.2 Multidisciplinary museums as a new and

promising category of exhibition spaces.

Modern researchers note that the convergence of traditional and digital art is not limited to the use of modern technical means for the display of traditional art works, as well as to the use of traditional Museum spaces for the display of digital art forms. The museum and exhibition environment itself is undergoing transformation, as well as its place in culture and the social roles it plays. Multimedia multidisciplinary art spaces are free now from the shackles of the historical context that cements the environment of classical art. Modern art spaces are becoming a place for visual demonstration of socio-cultural transitions not limited to the use of the fruits of scientific and technological progress.

...the easy belief that the museum would find a connection with technological advances just by using the latest (media) technology" But the museum cannot just take over the latest technologies and continue as before. "It must break away from the prevailing historistic, colonial, and elitist thinking that still shapes many of our museums today". Not least of all, art museums are cultural history museums, and they age with the way they convey their collections. Therefore, "the spread of networking thought dethrones the monodisciplinary art museum that has long been considered the queen of museums". [6]

\section{Conclusion}

Digital graphic design has a huge artistic potential in relation both to classical types of visual art as well as to modern media art. The richness of modern digital means of artistic expression, their rapid progress responsive to all current trends and requests of the artistic environment, as well as the maximum productivity of creation, replication and distribution of works, contribute to the growth of the penetration of digital graphic modeling in the socio-cultural environment and the share of computer art in the total number of media products consumed by civilization.

Due to the interdisciplinary nature of computer art it is quite natural to observe a dense convergence of various types and applications of digital art in the modern artistic environment. Already at the stage of creating works of three-dimensional graphics, the simultaneous creation of three-dimensional models and images for animation and cinematography, as well as for static use as replicated paintings and sculptures is common for modern mass art, which exists in a highly competitive environment and uses multiple channels of monetization of created artistic images in various types of works united by a common artistic design.

The major art projects of the pre-digital era can serve as an example of the active use of various types of art in a complex interconnected system at the production stage. An indispensable element of the production of feature films is a graphic and sculptural conceptual study as the basis of which the scenery costumes and props of the film are made. In the course of the digital revolution in cinema which began in the 70s of the XX century and has almos ended by now, almost all stages of artistic elaboration of the visual elements of films have completely passed into the field of digital graphic design, replac ing in an increasing proportion of cases conceptual sculpture and graphics. Nowadays, digital graphic design has made up a large part of the visual range of modern cinema, replacing material decorations, props, complex types of makeup and costumes, in some cases fully implementing the landscape part of the film. The technological advantages of digita art - first of all, the ease of reuse and refinement of digital models in order to produce related series of works - allow one to minimize the cost of creating modern digital models, embodying in the most complex of them the work of significant teams of artists, designers and programmers.

In the field of organizing exhibition spaces there is a convergence of traditional and digital art displays. Traditional forms are presented along with direct demonstration of completed works of digita graphic modeling and works of interactive demonstration tools that involve the viewer directly in the artistic context of a multimedia work, which allows one to modify the artistic images of the objects on display in a fascinating way, to be included personally in the system of digital objects. In a modern society that is extremely saturated with a variety of audiovisual programs, the so-called "culture of passive entertainment", such multimedia and interactive exhibition spaces offer a representative of the widest audience in the most favorable format to form a positive integral impression of the art space, which contributes to the popularization of graphic art in general, strengthening its role as one of the fundamental components of modern culture.

Digital means of multimedia artistic communication are becoming particularly relevant in condition of prolonged social crises of moderate intensity when a significant part of the population still retains a secure interest in art, but trips, trips to visit museum and exhibition institutions, as well as holding mass cultural events are becoming difficult to access economically and often directly impossible. This applies both to large-scale pandemics such as the current COVID-19 pandemic, and to hybrid confrontations that are now widespread in the world which are expressed in long-term military and political conflicts of low intensity. Electronic means of $c$ tivities in these conditions allow art to overcome distances, barriers and restrictions, are helping to reduce social and international tensions and develop a global cultural space. 

1. Adérito Marcos, Computer artefact: the crucial element
in artistic practice in digital art and Culture, Revista Lusófona de Estudos Culturais, vol. 3, n. 2, 2017, pp 149-166

2. Kevin McCarthy, Arthur Brooks, Julia Lowell, Laura Zakaras. The performing arts in a new era. ISBNO-83303041-8, 2001

3. Kluszczynski, R.W. 2007. "From Film to Interactive Art: Transformations in Media Arts", MediaArtHistories, ISBN-13: 978-0-262-07279-3, MIT Press, pp. 208-227

4. http://businesstravelrussia.ru/news/abt-partner-news/ event-live-geymifikatsiya-v-ivente-10-zhivykh-keysov/ https://moscow.arttube.ru/event/vy-stavka-virtual-nye-zerkala-konstantina-hudyakova/

Bast G., Carayannis E. G., Campbell D. F. 2018 Introduction: The Future of Museums. In: Bast $G$ Carayannis E., Campbell D. (eds) The Future of Museums. Arts, Research, Innovation and Society. Springer, Cham. https://doi.org/10.1007/978-3-319-93955-1_1

Virtual art: from illusion to immersion, Oliver Grau ISBNO-262-07241-6 The MIT Press 2003

https://www.dailykos.com/

stories/2019/4/14/1835230/-Immersive-Art

профессор

зав. кафедрой «Средовой дизайн» Московской государственной художественно-промышленной академии им. С.Г. Строганова

e-mail: lenartt@gmail.com

Москва, Россия

ORCID 0000-0002-5355-8565

Дарья Евгеньевна Кардашенко преподаватель

Московская государственная художественно-промышленной академия им. С.Г. Строганов

e-mail: dkardashenko@gmail.com

Москва, Россия

ORCID 0000-0001-5707-5319

DOI: 10.36340/2071-6818-2021-17-4-110-123

\section{ХУДОЖЕСТВЕННЫЙ ПОТЕНЦИАЛ ГРАФИЧЕСКОГО ЦИФРОВОГО МОДЕЛИРОВАНИЯ.}

КОНВЕРГЕНЦИЯ ТРАДИЦИОННЫХ И МУЛЬТИМЕДИЙНЫХ

ВЫСТАВОЧНЫХ СРЕДСТВ В ДЕМОНСТРАЦИИ ПРОИЗВЕДЕНИЙ ЦИФРОВОГО ИСКУССТВА

Аннотация: В статье рассмотрен художественный потенциал компьютерного графического моделирования в пространстве современного художественного творчества и художественных систем экспонирования. Пример современных выставочных событий реализует сложную конвергенцию традиционных и мультимедийных экспозиционных средств в демонстрации произведений цифрового искусства. В основу методологии исследования был положен аналитический обзор проектных технологий художественных произведений и выставочных пространств, использующих цифровые модели, в контексте современных векторов медиа культуры и медиа искусства. В силу органически присущей компьютерному искусству междисциплинарности, становится естественна наблюдаемая в художественной среде плотная конвергенция различных видов и приложений цифрового искусства на фоне традиционных структур Намеченные современные тендении мултти -

\section{1. Введение}

В настоящей работе ставится задача анализа влияния современных возможностей цифрового графического моделирования на процесс создания художественных произведений. Областью медийной трансформации выставочных пространств и как результат, созданные полидисциплинарные экспосреды, позволяют говорить о глубоком проникновении цифровых технологий в область искусства и культуры. Примером становятся цифровые музеи с неограниченным потенциалом средств выражения: от ультратрадиционалистских объектов до примеров современных виртуальных пространств. Результатом проведенного исследования явилась выработка рекомендаций по оптимальной организации среды демонстрации гибридных и цифровых произведений искусства. Сделанные выводы позволяют учесть перспективы развития инновационных выставочных пространств, а также оптимизировать функционирование экспозиционной сред с растущей долей цифрового графического контента Ключевые слова: диджитал арт, мультимедийная выставка, VR/AR в GLAM, геймификация, цифровые технологии.

исследования является обзор текущего состояния иифрового графического искусства, его художе ственного потенциала, основных доступных выразительных средств, а также анализ перспектив демонстрации произведений цифрового искус 
ства в среде, сочетающей традиционные и мультимедийные выставочные средства.

1.1. Значение средств цифрового графического моделирования в современном искусстве.

Зародившись в 60-е гг. XX в., компьютерная графика прошла значительный путь развития, от ранних экспериментов для научно-технических нужд и отдельных спецэффектов в крупнобюджетных кинолентах в 70-80-х, до прочного утверждения в различных видах искусства, начиная с 90-х годов. Современная эпоха демонстрирует тотальное доминирование цифровых технологий на массовом рынке художественного контента. Это связано как с огромным разнообразием инструментов художественного выражения, предоставляемым современными средствами графического моделирования, так и с высокой производительностью труда цифровой среды. Влияют и фактор гибкой интегрируемости различных видов контента, и удобство взаимодействия между отдельными художниками. В совокупности это даёт переход на новый уровень художественной выразительности, одновременно радикально увели чивая количество ежегодно создаваемых в мире произведений. Существенное снижение стоимости и непосредственных трудозатрат художников, вызванное внедрением цифрового моделирования, позволяет коллективам умеренной численности успешно реализовывать анимационные и кинематографические проекты, которые ранее создавались с огромными затратами и в течение долгого времени большими коллективами. Аналогично, небольшие команды и даже дизайнеры-одиночки, оснащённые богатым арсеналом программно-аппаратных средств, справляются с недоступным в классическую эпоху объёмом архитектурного и средового творчества.

1.2. Тенденции конвергенции традиционных и мультимедийных выставочных средств, наблюдаемые в настоящее время

Взрывной рост проникновения цифровых

рафических технологий в процесс создания графических технологий в процесс создания художественных произведений влечёт за со-
бой необходимость создания новых выставочных пространств. Во многих случаях, цифровые технологии не заменяют традиционные художественные произведения и не создают специализированные цифровые выставочные пространства, а осуществляют конвергенцию традиционного и цифрового искусства в единой экспосреде. Это позволяет существенно расширить целевую ауди торию, разнообразить впечатления, получаемые посетителями, и получить их позитивный отклик на экспозицию, что способствует коммерческому успеху выставок и повышению общественной му успеху выставок и повышению об

\section{2. Области применения цифровых средств} графического искусства.

\section{1. Компьютерные игры.}

Первые компьютерные игры стали появляться вскоре после появления первых эВМ, как эксперименты компьютерных энтузиастов. Графиче ские возможности и доступность компьютеров стремительно росли, в 70-80 годы стали появстемы с двумерной графикой, а в 90-е появилас трёхмерная игровая графика. На рубеже веков мейнстримом стало применение аппаратных возможностей ускорения трёхмерной графики большинство игровых систем получило специализированный вычислитель - графический процессор с аппаратными возможностями ускорени рендеринга полигональной графики в реальном времени. В первом десятилетии XXI века видеокарты сначала получили возможность ускорения шейдинга, а к концу десятилетия стали высокопроизводительными многопоточными вычислителя ми для задач общего назначения. Применительно к задачам цифрового искусства подобный рос доступной вычислительной мощности привёл следующим основным тенденциям:

- Графический дизайн трёхмерных компьютерных игр стремительно усложняется, применя емые модели по сложности двигаются в сторону кинематографических, а качество получаемого

на выходе изображения постепенно стремится к фотореалистичному.

- Программные системы реализации игровой среды (т.н. «движки») становятся мощным инструментом создания трёхмерных интерактивных арт-объектов. Как в случае графических процессоров: массовость производства способствует невысокой стоимости аппаратных средств, а мас совость рынка игрового программного обеспече ния способствует доступности сложных средств разработки игр для применения даже в единичных арт-объектах.

- Внедрение элементов искусственного интеллекта в интерактивные выставочные объекть позволяет трансформировать выставочные пространства, делая участие посетителя в работе си- стемы максимально простым, позволяя вовлечь посетителя традиционного музея в виртуальную среду без его персонального обслуживания ассистентом при объекте. Современные средства ввода информации в компьютер, являющиеся развитием современных игровых устройств ввода позволяют осуществлять захват движения посетителя, распознавание лиц и прочих частей тела. Результатом обработки в режиме реального времени могут быть как статичные двумерные изображения, так и трёхмерная анимация с участием посетителя

- Большую роль в выставочных пространствах научно-популярного направления, таких как технические и естественнонаучные муз получают близкие к компьютерным играм системы интерактивной наглядной симуляции требуемых природных явлений и технических объектов. Современные музеи получают возможность создания с умеренными затратами аттракционов-тренажёров, дающих посетителю опыт нового уровня по сравнению с традиционными статическими экспонатами. Это позволяет эффективно вовлечь современного массового посетителя, привычного к изобилию доступного аудиовизуального контента. И особенно это важно для выставочных пространств, ориенти рованных на детскую и молодёжную аудиторию. С другой стороны - аппаратная и программная унификация интерактивного симулятора с трёхмерными игровыми системами предоставляе уникальные возможности создания доступных систем дистанционной интерактивной симуляции. Современное положение дел в данной области радикально отличается от ситуации 30-40 летней давности. Тогда компьютерная трёхмерная графика, и создаваемые на её основе интерактивные тренажёры-симуляторы требовали применения дорогостоящих графических станций и могли быть использованы либо только в месте своей установки (как правило, в промышленности, будучи недоступными для широкого выставочного применения в силу высокой стоимости), либо служить инструментами производства тиражируемых визуальных произведений без интерактивного использования. В настоящее ремя, напротив, активно внедря. Всся систем на основе массовых коммерчески доступных компонентов. Например, специалисты компании Wargaming, совместно с представителями Мини стерства обороны РФ разместили в 2016 г. в Цен- тральном музее Вооружённых сил РФ в Москв интерактивную мультитач-панель, где в деталях представлены исторически достоверные 3D-модели более полусотни боевых кораблей основных классов пяти сверхдержав эпохи мировых войн XX века. Посетителям дали возможность ознакомиться с 3D-моделями, каждую из которых можно было подробно рассмотреть с любого ракурса и под любым углом, поворачивая их из стороны в сторону, приближая и удаляя на сенсорном экране. В свою очередь, все модели сопровождались историческими справкам и тактико-техническими характеристиками. [4] Следует заметить, что данное выставочное средство повторяет собой часть функционала коммерческого продукта Wargaming - онлайн-игры "World of Warships», симулятора морских сражений, а создание подобного интерактивного стенда является весьма экономически выгодным в сравнении с автономной разработкой выставочного стенда с нуля, т. К. используются и готовый движок игры, и уже имеющийся в игре рафический контент.

- На стыке компьютерных игр и промышленной компьютерной графики возникли и получили бурное развитие системы виртуальной и дополненной реальности. Как и в случае с самими массовыми игровыми системами, снижени стоимости при переходе к массовому производству позволило сделать средства виртуальной реальности доступными широкой аудитории и сочетать стационарные музейные комплекс VR- и AR-демонстрации художественных произ ведений с дистанционными технологиями, основанными на отлаженных и популярных стандартах массовых игровых систем.

Государственный музей изобразительных искусств имени A. С. Пушкина внедрил AR-приложение Artefact, бесплатное для скачивания в App Store $n$ Google Play. Наводя камеру мобильно го устройства на экспонат, отмеченный знаком можно просмотреть всю информацию прямо на экране своего устройства - узнать исторически факты о нём или, например, сравнить, как произведение выглядело до реставрации и в процессе реставрационных работ. [4]

Кафедра Средовой дизайн (профили Средовой дизайн и Мультимедиа дизайны) академии им. С. Г. Строганова в рамках учебных программ «Гейм-дизайн», «Моушен-дизайн», «Проектирование», «Разработка интерфейсов», «Анимация 
активно стремится обращаться к современным тенденциям - создавать виртуальные выставочные пространства, доступные в форме интернет-сайтов, проектировать приложения дополненной реальности, позволяющие осуществлять цифровую трансформацию существующей природной, индустриальной или урбанистической среды под выставочные и просветительские нужды, а также придавать широкий мультимедийный функционал традиционным выставочным средам - выставкам, музеям, экскурсионным программам, модернизируя сложившиеся художественные формации под современные условия посредством медиа-реконструкции.

- Становление массовой игровой индустрии и её прочная культурная интеграция породи ли новое социальное явление в организации разнообразных социальных процессов - геймификацию. Сущность геймификации состоит в применении игровых элементов и механик за пределами собственно игрового процесса. Геймификация позволяет эффективно мотивировать людей, основываясь на естественных потребностях в элементе азарта, получении регулярного потока оцениваемых достижений и подобных источников эмоций, избегающих явного давления и прочих негативно воспринимаемых механизмов.

Геймификация с большим успехом внедряет ся в различных отраслях деятельности человека. Применительно к популяризаторской и образовательной функции музеев, геймификация позволяет заменить опросы и прочие формальные методы тестирования восприятия изученного материала игрой, в которой сам тестируемый посетитель заинтересован в демонстрации полученных знаний. В случае продолжительного погружения путём установки на личный смартфон приложения с элементами геймификации, потребитель сможет быть мотивирован на посещение и углублённую проработку целого ряда выставочных пространств. Примером стали разрабатываемые в рамках программы «Проектирование» интерактивные приложения.

2.2. Арт-инсталляции с использованием гафического цифрового моделирования

Компьютерные технологии зачастую выполняют не только вспомогательные технические функции по демонстрации произведений традиционного искусства или привнесения в выставочную среду интерактивности, но и могут состояться как самоценные арт-объекты. С каждым годом появляется всё большее количество художников, предпочитающих в своём творчестве использовать исключительно виртуальную среду. В качестве одного из примеров можно привести американского художник А. Джонса, который называет свои исключи тельно цифровые работы «зеркальным чисти лищем» и основной целью своего творчества считает изменение восприятия действительности и погружение человеческого сознания в виртуальную реальность.

Если творческие изыскания А. Джонса лежаг в основном в плоскости 2D-графики, то работы президента Творческого союза художников К. В. Худякова, которого называют «первопроходцем российской цифровой скульптуры» ос новываются на работе с трёхмерной графикой. «Oн заменил мрамор и резец на 3D Studio Max AutoCad и 3D принтер» [5]

2.3. Художественный потенциал цифровой графики как части непрерывного пространств мультимедийных компьютерных искусств.

Рассмотренные сферы применения цифровых средств соответствуют общей специфике цифрового искусства, неразрывно объединяющего в совокупности цифровых носителей информации и работающей с ними вычислительной техники существовавшие отдельно понятия традицион ного искусства, как творческий инструмент и необработанные художественные материалы.

Рис. 1. Взаимосвязь средств и материалов художественного выражения для различных соот ношений физического и виртуального уровня реализации художественных объектов в контексте конвергентного искусства. [1]

Такой характер связи позволяет художнику отойти от прямолинейного переноса традици онных видов и жанров изобразительного искус ства в цифровую среду, а заниматься творческим поиском в интегральной среде цифрового искусства, объеди инструменты моделирования, визуализации и параметризации, в том числе интерактивной.

В силу глубокого взаимного проникновения трансформированных классических художественных форм в условиях мультимедийной цифровой среды, неудивительно размытие отдельных видов искусства в реалиях компьютерного творческого процесса. В современных условиях первостепенное значение для успеха цифрового художествен- ного произведения приобретает управление его циклом создания и экспонирования с учётом актуальных реалий социокультурной среды. Данный фактор становитса ключевым в условиях всеобщего охвата цивилизации механизмами доставки и демонстрации медиаконтента, когда и дефицит доступности просмотра, и эксклюзивность медиакопии (атрибуты традиционного изобразительного искусства) больше не являются доми нирующими факторами привлечения интереса к произведению. Принципиальным моментом для успеха арт-ивентов в таких условиях становится создание достаточно обширной и одновременно целостной идейно-контентной среды, позволяющей посетителю получить принципиально иной, по отношению к клиповой повседневной среде, эстетический опыт.

Рис. 2 Общие факторы создания художественного произведения как интегрированного в культурную среду средства достижения отклика широкой аудитории [1]

Схема на рис. 2 демонстрирует современное видение цикла создания цифрового художе ственного произведения как средства достижения глобальных культурных целей - донесения творческого замысла, воплощённого в средствах художественного выражения, до общественности, путём задействования оптимизации средств демонстрации как неотъемлемой части цикла создания арт-объекта.

3. Конвергенция традиционных и мультим. Конй втставочных средств в демонстрации произведений цифрового искусства

3.1. Возникновение и развитие иммерсив ных форм искусства.

Эффект присутствия, «погружения» зрителя в создаваемую изобразительным художественным произведением атмосферу, был желанной целью задолго до возникновения цифрового искусства. Масштабные живописные панно, комбинирование станковой, монументальной и декоративной живописи в едином пространстве живописные и графические иллюзии, панорамы, средства проекционной демонстрации статических изображений и кинематограф с нарастающей панорамностью, вплоть до полнокупольной проекции - все эти инструменты использовались для усиления впечатления от художественных произведений. Однако, лишь с появлением мультимедийных средств цифрового искусства, стало возможным достижение полноценной иммерсив- ности. Современные средства демонстрации про изведений цифрового искусства позволяют без экстраординарных затрат на производство гра作 вниманием зрителя, доносить художественный замысел одновременным воздействием на различные органы чувств, а при необходимости дополнять получаемые впечатления элементами интерактивности.

Современное применение иммерсивных выставочных пространств охватывает широчайший спектр вариаций [7], от трансформации произ ведений классической живописи в иммерсивные выставочные пространства [8] до создания специализированных мультимедийных произведений для иммерсивной среды. Помимо художественных выставок, успешное применение иммерсивные пространства находят и в научно-просветительской экспозиционной среде.

3.2. Мультидисциплинарные музеи как новая и перспективная категория выставочных пространств.

Современные исследователи отмечают, что конвергенция традиционного и цифрового ис кусства не сводится лишь к применению современных технических средств для демонстрации традиционных художественных произведений, равно как и к использованию традиционных музейных пространств для демонстрации цифровых форм искусства. Трансформации подвергается как сама музейно-выставочная среда, так и её место в культуре, выполняемые ею социальные роли. Мультимедийные мультидисциплинарные художественные пространства динамично освобождаются от оков исторического контекста, цементирующего среду классического искусства. Современные художественные пространства становятся местом наглядной демонстрации соци окультурных переходов, не ограничиваясь лиш применением плодов научно-технического прогресса.

"...the easy belief that the museum would find a connection with technological advances just by using the latest (media) technology" But the museum cannot just take over the latest technologies and continue as before. "It must break away from the prevailing historistic, colonial, and elitist thinking that still shapes many of our museums today". Not least of all, art museums are cultural history museums, and they age with the way they convey their collections. 
Therefore, "the spread of networking thought dethrones the monodisciplinary art museum that has long been considered the queen of museums".[6]

\section{4. Заключение}

Цифровой графический дизайн обладает огромным художественным потенциалом как применительно к классическим видам изобразительного искусства, так и в отношении современного медиа-искусства. Богатство современных цифровых средств художественного выражения их быстрый прогресс, чутко реагирующий на все актуальные тенденции и запросы художественной среды, а также максимальная производительность создания, тиражирования и распространения произведений, способствуют росту проникновения цифрового графического моделирования в социокультурную среду и доли компьютерноо искусства в общем количестве потребляемых цивилизацией медиа-продуктов.

В силу органически присущей компьютерному искусству междисциплинарности, совершенно естественна наблюдаемая в современной художественной среде плотная конвергенция различ ных видов и приложений цифрового искусства. Уже на стадии создания произведений трёхмерной графики широко распространено одновременное создание трёхмерных моделей и образов как для анимации и кинематографии, так и для статичного использования в качестве тиражиру емых картин и скульптур - характерно для современного массового искусства, существующего в условиях высоко конкурентной среды и использующего множественные каналы монетизации создаваемых художественных образов в различ ных видах произведений, объединённых общим художественным замыслом.

Примером активного использования различ ных видов искусства в сложной взаимосвязанной системе на стадии производства становилис крупные художественные проекты доцифровой эпохи. Непременным элементом производства игрового кино является графическая и скульптурная концептуальная проработка, на основании которой выполняются декорации, костюмы и реквизит киноленты. В ходе цифровой революции в кинематографе, начавшейся в 70-х годах XX в. и почти завершившейся к настоящему времени практически все этапы художественной проработки изобразительных элементов кинофильмов полностью перешли в область цифрового графи ческого дизайна, заменяющего во всё большей доле случаев концептуальные скульптуру и графику. В настоящее время, цифровой графический дизайн составил большую часть визуального ряда современного кино, заменяя материальные декорации, реквизит, сложные виды грима и костюмь в ряде случаев, полностью реализуя ландшафтную часть киноленты. Технологические преи мущества цифрового искусства 一прежде всего лёгкость повторного использования и доработок цифровых моделей с целью выпуска связанных серий произведений, позволяют минимизировать затраты на создание современных цифровых моделей, воплощая в наиболее сложных из них труд значительных коллективов художников, дизайнеров и программистов.

В области организации выставочных пространств наблюдается конвергенция демонстрации традиционных и цифровых видов искусств. Традиционные виды представлены наряду с непосредственной демонстрацией законченных произведений цифрового графического модели рования и работ интерактивных средств демонстрации, вовлекающих зрителя непосредственно в художественный контекст мультимедийного произведения, что позволяет в увлекательной форме модифицировать художественные образы экспонируемых объектов, лично включатьс в систему цифровых объектов. В современном обществе, крайне насыщенном разнообразными аудиовизуальными программами, т. н. «культуре пассивного развлечения», подобные мультимедийно-интерактивные выставочные пространства предлагают представителю самой широкой аудитории в наиболее благоприятном формате сформировать позитивное интегральное впе чатление от художественного пространства, что способствует популяризации графического искусства в целом, укрепляя его роль, как одной из фундаментальных составляющих современной культуры.

Особо актуальными становятся цифровые средства мультимедийной художественной коммуникации в условиях затяжных социальных кризисов умеренной интенсивности, когда значительная часть населения ещё сохраняет обеспеченны интерес к искусству, но поездки, путешествия с целью посещения музейно-выставочных учреждений, а также проведение массовых культурных мероприятий становятся и труднодоступными экономически, и нередко прямо невозможными организационно. Это относится как к масштабным пандемиям, как имеющая место в настоящее время пандемия COVID-19, так и к распространённым сейчас в мире гибридным противостояниям выражающимся в долговременных военно-политических конфликтах низкой интенсивности. Электронные средства коммуникации и виртуаль-

БИБЛИОГРАФИЯ

1. Adérito Marcos. Computer artefact: the crucial element in artistic practice in digital art and Culture, Revista in artistic practice in digital art and Culture, Revista 2017. - P. 149-166.

2. The performing arts in a new era / Kevin McCarthy, The performing arts in a new era / Kevin McCarthy,
Arthur Brooks, Julia Lowell, Laura Zakaras. - ISBNOArthur Brooks, Julia Low

3. Ryszard W. Kluszczynski From Film to Interactive Art Transformations in Media Arts/MediaAthistories; 2006. - P. 208-227. ной выставочной деятельности в этих условиях позволяют искусству преодолевать расстояния, барьеры и ограничения, способствовать снижести, развивать глобальное культурно-ценностное пространство. http//businesstravelrussia.ru/news/abt-partner-news/ event-live-geymifikatsiya-v-ivente-10-zhivykh-keysov/ 5. https://moscow.arttube.ru/event/vy-stavka-virtual-nye-zerkala-konstantina-hudyakova/

Rest G. et al. (eds.). The Future of Museums, Arts, Rearch, Innovation and Society. - URL: https://do org/10.1007/978-3-319-93955-1_

. 8.

stories/2019/4/14/1835230/-Immersive-Art 